\title{
Substratos na indução e desenvolvimento in vitro de raízes em dois porta-enxertos de macieira ${ }^{(1)}$
}

\author{
Alexandre Hoffmann ${ }^{(2)}$, Moacir Pasqual(3), Nilton Nagib Jorge Chalfun ${ }^{(3)}$ e Sílvia Serra Negra Vieira ${ }^{(4)}$ \\ Resumo - Este trabalho teve como objetivo estudar o efeito da vermiculita e do Plantmax como substratos \\ alternativos ao ágar durante a indução e o desenvolvimento in vitro de raízes dos porta-enxertos de \\ macieira 'Marubakaido' e 'M-26'. Foram utilizadas brotações apicais previamente cultivadas in vitro. \\ $\mathrm{O}$ experimento foi dividido em duas fases. Na primeira fase, os tratamentos consistiram no uso de três \\ substratos para a indução do enraizamento: ágar, Plantmax + ágar e vermiculita + ágar, com meio MS/2 \\ acrescido de vitaminas, glicina, mio-inositol, sacarose e ácido indolbutírico (AIB). Após sete dias neste \\ meio, as brotações foram recultivadas para meio MS com ágar $\left(7 \mathrm{~g} \mathrm{~L}^{-1}\right)$, sem AIB. Na segunda fase, \\ foram testados três substratos para o desenvolvimento das raízes adventícias (ágar, Plantmax e vermiculita, \\ umedecidas com meio MS), após sete dias de indução em meio com ágar $\left(7 \mathrm{~g} \mathrm{~L}^{-1}\right)$. O efeito dos tratamen- \\ tos foi estudado no ambiente in vitro e durante a aclimatização das plantas. O ágar, na fase de indução \\ do enraizamento e o ágar ou Plantmax, na fase de desenvolvimento das raízes adventícias, proporciona- \\ ram os melhores resultados, tanto para 'Marubakaido' como para 'M-26', no enraizamento in vitro e \\ durante a aclimatização.
}

Termos para indexação: cultura de tecidos, enraizamento, raízes adventícias, micropropagação, vermiculita.

\section{Substrates for in vitro adventitious root induction and development on two apple rootstocks}

Abstract - This work was carried out to study the effect of vermiculite and Plantmax as alternative substrates for agar during both in vitro rooting induction and adventitious root development on 'Marubakaido' and 'M-26' apple (Malus domestica Borkh.) rootstocks. Apical shoots previously maintained in vitro were used. This experiment was divided in two phases. On phase 1, treatments were constituted by three substrates for rooting induction: agar, Plantmax + agar and vermiculite + agar, with MS/2 medium with vitamins, glicyne, myinositol, sucrose and indolebutyric acid (IBA). After seven days in this medium, shoots were transferred to medium with agar $\left(7 \mathrm{~g} \mathrm{~L}^{-1}\right)$ and without IBA. On phase 2, three substrates were assayed for adventitious roots development (agar, Plantmax and vermiculite, wettish with MS medium) after a seven-day induction time on a medium with agar $\left(7 \mathrm{~g} \mathrm{~L}^{-1}\right)$. The effect of treatments was evaluated both in vitro and during environment acclimatization. The use of agar during rooting induction and agar or Plantmax, during adventitious root development provided the best results for 'Marubakaido' and 'M-26' plantlets, on in vitro rooting and during acclimatization.

Index terms: tissue culture, rooting, adventitious roots, micropropagation, vermiculites.

\section{Introdução}

A cultura da macieira apresenta grande importância no cenário frutícola brasileiro e mundial.

(1) Aceito para publicação em 16 de fevereiro de 2001.

Extraído da Tese de Doutorado do primeiro autor apresentada à Universidade Federal de Lavras (Ufla), Lavras, MG.

(2) Embrapa-Centro Nacional de Pesquisa de Uva e Vinho, Caixa Postal 130, CEP 95700-000 Bento Gonçalves, RS E-mail: hoffmann@enpuv.embrapa.br

(3) Ufla, Dep. de Agricultura, Caixa Postal 37, CEP 37200-000 Lavras, MG. E-mail: mpasqual@ufla.br, dag@ufla.br

(4) Ufla. Bolsista do Pibic/CNPq. E-mail: ssnv@ufla.br
Nos últimos 25 anos, a produção brasileira evoluiu de forma a atender a quase toda a demanda interna de maçãs. O uso de mudas de alta qualidade é um dos requisitos para a elevada produtividade e longevidade dos pomares e, para tanto, a micropropagação destaca-se como técnica para produção de mudas isentas de doenças, principalmente viroses.

O método convencional de micropropagação consiste no enraizamento in vitro de brotações em meio geleificado com ágar, com a posterior transferência das plantas enraizadas para casa de vegetação. Porém, o sistema radicular adventício emitido em meio 
semi-solidificado com ágar ou produto equivalente é, em geral, pouco ramificado, quebradiço e isento de pêlos radiculares (Leite, 1995), de modo que as raízes assim formadas são pouco eficientes na $a b-$ sorção de água e nutrientes durante a aclimatização. Apter et al. (1993) e Leite (1995) também apontam a baixa qualidade da raiz formada em ágar como uma das causas da baixa sobrevivência das plantas durante a aclimatização, além de ser o componente de maior custo do meio de cultura.

O efeito do substrato pode ser variável conforme a fase do enraizamento em que se utiliza um ou outro tipo. Segundo Grattapaglia \& Machado (1998), a rizogênese pode ser dividida em três fases: indução, iniciação e alongamento. Assim, é provável que, de acordo com o material utilizado como substrato em cada fase, os resultados sobre o porcentual de enraizamento ou mesmo sobre o padrão de desenvolvimento das raízes adventícias poderão afetar a sobrevivência e o crescimento das plantas durante a aclimatização.

O uso de substratos alternativos para o enraizamento visando a obtenção de um sistema radicular mais apropriado para a adaptação da planta em casa de vegetação já foi testado em diversos trabalhos e pode ser útil em sistemas intensivos de micropropagação. Grattapaglia \& Machado (1998) mencionam que a vermiculita, perlita ou espumas de poliuretano embebidas com meio líquido podem ser alternativas mais baratas e dar melhores resultados que o ágar. Hutchinson (1984), trabalhando com enraizamento de explantes de macieira 'Northern Spy' em meio líquido e em meios com areia grossa, perlita ou ágar, obteve 90 a $100 \%$ de iniciação de raízes nos três meios, mas houve pouco crescimento das raízes em ágar. Leite (1995) obteve, em relação ao ágar, maior ramificação do sistema radicular e maior densidade de pêlos absorventes em explantes de pereira com a utilização de vermiculita como substrato para enraizamento, concluindo que este material substitui com vantagens o ágar, além de ser mais barato. Navatel \& Bourrain (1994) obtiveram maior crescimento apical em mudas de macieira e nogueira micropropagadas, durante a aclimatização, quando o enraizamento ocorreu em vermiculita umedecida com meio MS líquido.
Este trabalho teve como objetivo estudar o efeito de diferentes substratos, alternativos ao ágar, sobre o enraizamento e a aclimatização de plantas micropropagadas dos porta-enxertos de macieira 'Marubakaido' e 'M-26' nas fases de indução do enraizamento in vitro, bem como de desenvolvimento das raízes adventícias.

\section{Material e Métodos}

O experimento foi realizado utilizando brotações apicais dos porta-enxertos de macieira 'Marubakaido' (Malus prunifolia) e 'M-26' (Malus sp.), obtidas in vitro. $\mathrm{Na}$ transferência para o meio de enraizamento, as brotações foram preparadas com cerca de 2 a $3 \mathrm{~cm}$ de comprimento (4 a 6 gemas), retirando-se as folhas inferiores e mantendo-se o meristema apical e dois pares de folhas próximas ao meristema.

Foram testados três substratos para a indução do enraizamento in vitro e três substratos para o desenvolvimento das raízes adventícias em brotações dos dois portaenxertos. O experimento foi desenvolvido em duas fases.

Na primeira fase, metade das brotações dos dois portaenxertos foram recultivadas para meio de cultura com a metade da concentração dos sais de MS (Murashige \& Skoog, 1962), acrescido de vitaminas $\left(1,5 \mathrm{mg} \mathrm{L}^{-1}\right)$, glicina (2,0 $\left.\mathrm{mg} \mathrm{L}^{-1}\right)$, mio-inositol $\left(100 \mathrm{mg} \mathrm{L}^{-1}\right)$, sacarose $\left(30 \mathrm{~g} \mathrm{~L}^{-1}\right)$ e $\operatorname{AIB}\left(1,0 \mathrm{mg} \mathrm{L}^{-1}\right)$. Os tratamentos consistiram no uso de três substratos para a indução do enraizamento: ágar (4,2 $\left.\mathrm{g} \mathrm{L}^{-1}\right)$; Plantmax (36 g/frasco) + ágar $\left(2,8 \mathrm{~g} \mathrm{~L}^{-1}\right) \mathrm{e}$ vermiculita de grânulos finos $(7,2 \mathrm{~g} /$ frasco $)+$ ágar $\left(2,8 \mathrm{~g} \mathrm{~L}^{-1}\right)$. Plantmax é um substrato comercial, elaborado com vermiculita expandida e materiais orgânicos de origem vegetal, isento de pragas, doenças e invasoras. Em cada frasco $\left(250 \mathrm{~cm}^{3}\right)$, foram adicionados $40 \mathrm{~mL}$ de meio de cultura. $\mathrm{O}$ período de indução do enraizamento foi de sete dias, em sala de crescimento com temperatura de $27 \pm 2^{\circ} \mathrm{C}$, fotoperíodo de 16 horas e luminosidade de $47 \mu \mathrm{mol} \mathrm{m} \mathrm{m}^{-2} \mathrm{~s}^{-1}$, proporcionada por lâmpadas fluorescentes brancas de 40 watts. Após a indução, as brotações foram transferidas para o meio de cultura com a concentração normal dos sais de MS, vitaminas, glicina e mio-inositol, porém isento de $\mathrm{AIB}$ e solidificado com $7 \mathrm{~g} \mathrm{~L}^{-1}$ de ágar, para desenvolvimento das raízes adventícias.

$\mathrm{Na}$ segunda fase, metade das brotações dos dois portaenxertos foram recultivadas para meio de cultura de indução do enraizamento, com metade da concentração dos sais de MS, acrescido de vitaminas $\left(1,5 \mathrm{mg} \mathrm{L}^{-1}\right)$, glicina (2,0 mg L $\left.\mathrm{L}^{-1}\right)$ e mio-inositol $\left(100 \mathrm{mg} \mathrm{L}^{-1}\right)$, sacarose $\left(30 \mathrm{~g} \mathrm{~L}^{-1}\right)$ e $\operatorname{AIB}\left(1,0 \mathrm{mg} \mathrm{L}^{-1}\right)$, solidificado com ágar $\left(7 \mathrm{~g} \mathrm{~L}^{-1}\right)$, onde 
foram mantidas durante sete dias, em frascos com $250 \mathrm{~cm}^{3}$ de capacidade. Os tratamentos consistiram no uso de três substratos para desenvolvimento das raízes adventícias: ágar ( $\left.7 \mathrm{~g} \mathrm{~L}^{-1}\right)$, Plantmax (48 g/frasco) e vermiculita de grânulos finos ( $14 \mathrm{~g} /$ frasco), nos quais foram adicionados $40 \mathrm{~mL}$ de meio de cultura MS, com a concentração normal dos sais e isento de AIB.

O período de desenvolvimento das raízes adventícias em ambas as fases foi de 49 dias. Na primeira etapa, durante o enraizamento in vitro, foi avaliado o porcentual de brotações enraizadas a cada sete dias. Após o enraizamento in vitro, foram avaliados o porcentual de brotações enraizadas, número de raízes primárias e altura da planta ou brotação nãoenraizada. Em ambas as etapas, foram utilizadas sete brotações/frasco

Após o período de enraizamento, as raízes das plantas ou a base das brotações foram lavadas com água destilada e, tanto as brotações enraizadas quanto as não-enraizadas, foram recultivadas para substrato comercial (Plantmax), acondicionado em bandejas de isopor com 128 células de $50 \mathrm{~cm}^{3}$ cada, e levadas para aclimatização em casa de vegetação com nebulização intermitente e sombreamento parcial proporcionado por dupla camada de tela de sombreamento. Após 49 dias de aclimatização foi realizada a avaliação final, sendo determinados a sobrevivência, altura da planta, número de raízes primárias e matéria seca da raiz e da parte aérea.

Foi adotado o delineamento experimental inteiramente ao acaso, com quatro repetições e sete brotações ou plantas por repetição. Em relação às variáveis número de raízes primárias, porcentual de enraizamento, altura e sobrevivência de plantas, quando tomadas periodicamente, foi adotado o esquema de parcelas subdivididas no tempo. Os dados foram submetidos à análise de variância e as médias comparadas pelo teste de Tukey a $5 \%$ de probabilidade.

\section{Resultados e Discussão}

\section{Primeira fase: Substratos na indução do enrai- zamento}

O porcentual de brotações enraizadas evoluiu ao longo do tempo de forma diferenciada entre os tratamentos, tendo ocorrido interação significativa entre os fatores tempo, porta-enxerto e substrato. Em 'Marubakaido', houve aumento linear do porcentual de enraizamento quando este foi induzido em ágar, e quadrático quando a indução ocorreu em vermiculita + ágar ou Plantmax + ágar (Figura 1). Quanto ao porta-enxerto 'M-26', observou-se comportamento semelhante (Figura 2), exceto quando utilizado o Plantmax + ágar como substrato para indução, no qual não houve formação de raízes adventícias. Quando utilizada a vermiculita, há maior aeração, necessária ao fornecimento de oxigênio para a respiração, o que proporcionou resposta mais rápida em emissão de raízes após o recultivo (Leite, 1995; Druart et al., 1997). Porém, ao se aproximar o final do período para enraizamento (49 dias), os porcentuais de brotações enraizadas foram semelhantes entre ágar e ágar + vermiculita ('Marubakaido'), e superiores em ágar ('M-26').

Após 49 dias de permanência das brotações em meio para desenvolvimento das raízes adventícias, observou-se interação entre os fatores porta-enxer-

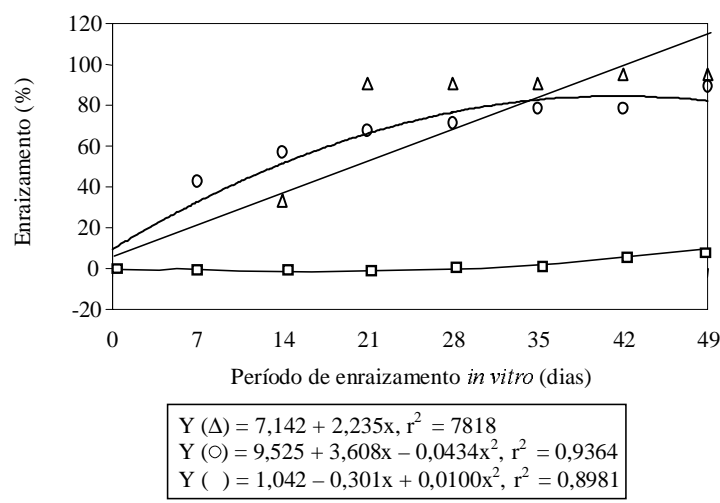

Figura 1. Evolução do porcentual de brotações de macieira 'Marubakaido' enraizadas in vitro, sob efeito de diferentes substratos ( $\Delta$ : ágar; O: vermiculita; $\square$ : plantmax) para indução do enraizamento. Lavras, Ufla, 1999.

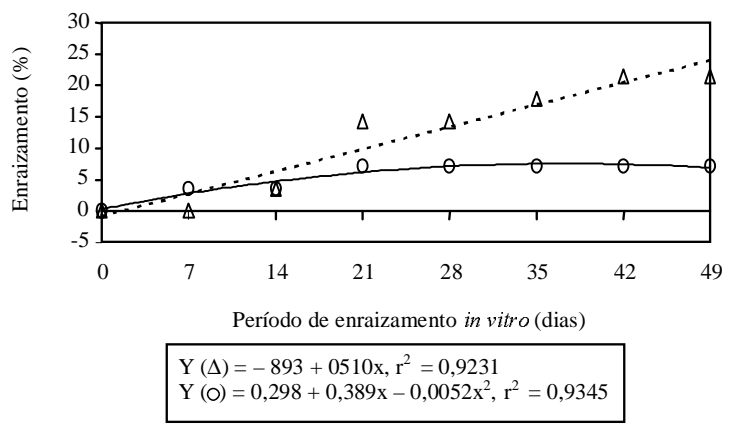

Figura 2. Evolução do porcentual de brotações de macieira 'M-26' enraizadas in vitro, sob efeito de dois substratos ( $\Delta$ : ágar; $\mathrm{O}$ : vermiculita) para indução do enraizamento. Lavras, Ufla, 1999. 
to e substrato na indução em relação à variável enraizamento (Tabela 1). A indução do enraizamento em ágar e vermiculita + ágar ('Marubakaido') e em ágar ('M-26') proporcionou os maiores porcentuais de enraizamento. Tanto em ágar quanto em vermiculita + ágar, houve diferença significativa entre os porta-enxertos. Em 'Marubakaido', os porcentuais foram de 95,24 e $89,28 \%$ e, em 'M-26', de 21,43 e $7,15 \%$, respectivamente, indicando a dificuldade de enraizamento do porta-enxerto ' $\mathrm{M}-26$ '. A facilidade de enraizamento de 'Marubakaido' também foi apontada por Jones \& Aldwinckle (1991). Não houve diferença entre os porta-enxertos apenas quando utilizado o Plantmax + ágar, pois nesse caso ocorreram porcentuais muito baixos de enraizamento nos dois porta-enxertos. Nunes et al. (1999) observaram que o Plantmax não foi eficiente como substrato para a aclimatização de 'Marubakaido', o que foi atribuído à sua composição química, prevista para o uso na produção de mudas de hortaliças e não especificamente para uso com plantas oriundas do ambiente in vitro.

$\mathrm{O}$ número de raízes primárias emitidas nas brotações de 'Marubakaido' foi significativamente superior quando utilizado o ágar como substrato para indução, e em 'M-26' não houve diferença entre os substratos. Quando a indução ocorreu em ágar e em vermiculita + ágar, o número de raízes primárias foi superior em 'Marubakaido', em relação a 'M-26'. Em ambos os porta-enxertos, o ágar proporcionou o maior crescimento em altura da planta ou brotação, e não houve diferença entre os porta-enxertos apenas quando utilizado o Plantmax + ágar na indução do enraizamento. Genótipos com maior dificuldade de enraizamento tendem a manifestar ainda mais problemas quando expostos a condições menos favoráveis (Haissig \& Riemenschneider, 1988). Simões (1988), trabalhando com laranjeira 'Pera', observou que o meio de cultura condicionou o padrão morfológico das raízes. Segundo o mesmo autor, as raízes crescidas em ágar, ao continuarem seu desenvolvimento em vermiculita, desenvolveram estrutura semelhante à de raízes oriundas de sementes, possuindo pêlos absorventes, córtex mais compacto e com espaços intercelulares menores.

Após 49 dias de aclimatização, a sobrevivência de plantas de 'Marubakaido' foi superior quando a indução do enraizamento ocorreu em Plantmax + ágar $(78,6 \%)$ e em vermiculita + ágar $(50,0 \%)$, caracterizando o efeito da aeração do substrato sobre a resistência física e fisiológica das mudas à aclimatização, mesmo considerando o tempo posterior de enraizamento in vitro (Tabela 2). Este resultado está de acordo com Le \& Collet (1991), os quais, traba-

Tabela 1. Porcentual de brotações enraizadas, número de raízes primárias e altura da planta ou brotação de dois portaenxertos de macieira após 49 dias de enraizamento in vitro sob efeito de três substratos para indução do enraizamento. Lavras, Ufla, 1999(1)

\begin{tabular}{|c|c|c|c|c|c|c|}
\hline \multirow[t]{2}{*}{ Substrato } & \multicolumn{2}{|c|}{ Enraizamento (\%) } & \multicolumn{2}{|c|}{ Raízes primárias $\left(\mathrm{n}^{\circ}\right)$} & \multicolumn{2}{|c|}{ Altura da planta $(\mathrm{cm})$} \\
\hline & Marubakaido & M-26 & Marubakaido & M-26 & Marubakaido & M-26 \\
\hline Ágar & $95,24 \mathrm{aA}$ & $21,43 \mathrm{aB}$ & $6,37 \mathrm{aA}$ & $1,25 \mathrm{aB}$ & $1,67 \mathrm{aA}$ & $1,18 \mathrm{aB}$ \\
\hline Vermiculita + ágar & $89,28 \mathrm{aA}$ & $7,15 \mathrm{aB}$ & $3,31 \mathrm{bA}$ & $1,25 \mathrm{aB}$ & $1,18 \mathrm{bA}$ & $0,45 b B$ \\
\hline Plantmax + ágar & $10,72 \mathrm{bA}$ & $0,00 \mathrm{bA}$ & $0,50 \mathrm{cA}$ & $0,00 \mathrm{aA}$ & $0,72 \mathrm{cA}$ & $0,43 \mathrm{bA}$ \\
\hline
\end{tabular}

${ }^{(1)}$ Médias seguidas de mesma letra, minúscula na coluna e maiúscula na linha, não diferem entre si, pelo teste de Tukey a $5 \%$ de probabilidade; os coeficientes de variação em relação ao enraizamento, número de raízes primárias e altura da planta foram de $13,98 \%, 15,61 \%$ e $19,38 \%$, respectivamente

Tabela 2. Sobrevivência e número de raízes primárias de dois porta-enxertos de macieira, após 49 dias de aclimatização, sob efeito de três substratos para indução do enraizamento. Lavras, Ufla, 1999(1).

\begin{tabular}{lccccc}
\hline \multirow{2}{*}{ Substrato } & \multicolumn{2}{c}{ Sobrevivência $(\%)$} & & \multicolumn{2}{c}{ Raízes primárias $\left(\mathrm{n}^{\circ}\right)$} \\
\cline { 2 - 3 } \cline { 5 - 6 } & Marubakaido & M-26 & & Marubakaido & M-26 \\
\hline Ágar & $38,10 \mathrm{bA}$ & $39,28 \mathrm{aA}$ & & $15,08 \mathrm{aA}$ & $3,88 \mathrm{aB}$ \\
Vermiculita + ágar & $50,00 \mathrm{abA}$ & $28,57 \mathrm{aA}$ & & $8,00 \mathrm{bA}$ & $3,17 \mathrm{aA}$ \\
Plantmax + ágar & $78,57 \mathrm{aA}$ & $25,00 \mathrm{aB}$ & & $6,25 \mathrm{bA}$ & $2,25 \mathrm{aA}$ \\
\hline
\end{tabular}

(1)Médias seguidas de mesma letra, minúscula na coluna e maiúscula na linha, não diferem entre si pelo teste de Tukey a $5 \%$ de probabilidade, os coeficientes de variação em relação à sobrevivência, e ao número de raízes primárias foram de $25,50 \%$ e 20,75\%, respectivamente. 
lhando com enraizamento dos porta-enxertos ' $\mathrm{M}-26$ ' e 'Mac 9', comprovaram que a sobrevivência e o desenvolvimento das mudas durante a aclimatização é estreitamente dependente do substrato e da cultivar. Com 'M-26', não houve efeito do substrato sobre esta variável. A diferença entre os dois porta-enxertos somente foi observada quando usado o Plantmax + ágar. Embora quando utilizado o Plantmax + ágar como substrato de indução o enraizamento in vitro tenha sido próximo de zero ('Marubakaido') ou nulo ('M-26'), verifica-se a superioridade deste substrato na sobrevivência das plantas. Como foram repicadas todas as brotações, independentemente da formação de raízes, a qual ocorreu somente após as brotações terem sido transferidas para a aclimatização, pode-se deduzir que o enraizamento ocorreu até mesmo ex vitro, após os sete dias de indução em Plantmax + ágar. O número de raízes primárias foi afetado pelo substrato de indução do enraizamento apenas em 'Marubakaido', sendo que a indução em meio com ágar proporcionou o maior valor (15,1 raízes/planta), de acordo com o que foi observado quando as plantas foram retiradas do cultivo in vitro. A diferença entre os substratos foi observada apenas quando utilizado o ágar.

\section{Segunda fase: Substratos no desenvolvimento in vitro de raízes}

Após 49 dias de enraizamento in vitro, a altura das brotações (enraizadas e não-enraizadas) foi afetada pelos fatores substrato e porta-enxerto, sendo a interação porta-enxerto x substrato não-significativa. Nos três substratos, a altura das plantas do porta-enxerto 'M-26' foi significativamente inferior à das plantas de 'Marubakaido' (Tabela 3). Em 'Marubakaido', o desenvolvimento das raízes adventícias em meio com ágar ou com vermiculita proporcionou maior altura das plantas, em relação ao Plantmax, ao passo que em
'M-26' o ágar proporcionou valores superiores aos da vermiculita e do Plantmax. Possivelmente, a maior facilidade de acesso dos nutrientes ao explante no meio solidificado com ágar foi o principal fator a contribuir para esse resultado. O contato físico do substrato com o explante tende a favorecer 0 enraizamento (McCown, 1988), e isto foi notado principalmente com o ágar. Além disso, a alta capacidade de adsorção de nutrientes pela vermiculita (Hartmann et al., 1990) pode ter tido influência sobre os resultados. Quando utilizado o ágar como substrato para o enraizamento, o número de raízes primárias foi superior em 'Marubakaido', exceto quando utilizado o Plantmax, no qual o número de raízes em 'M-26' foi superior em relação ao 'Marubakaido' (Tabela 3). Apenas quando utilizada a vermiculita não houve diferença entre os porta-enxertos, devido aos baixos valores obtidos com este substrato.

O porcentual de enraizamento de brotações foi afetado pelo substrato, em ambos os porta-enxertos, somente havendo diferenças entre porta-enxertos quando utilizado o Plantmax para desenvolvimento das raízes (Tabela 4). Em 'Marubakaido' o ágar proporcionou o maior porcentual de enraizamento (85,71\%), ao passo que em 'M-26', tanto o ágar quanto o Plantmax foram eficientes como substratos para desenvolvimento in vitro das raízes adventícias (72,14 e 71,14\%, respectivamente). Segundo George (1993), o enraizamento in vitro em substratos porosos, como areia, perlita, espuma e outros, também facilita a repicagem, pois as plantas podem ser transferidas do frasco de cultura com poucos danos às raízes. Collet et al. (1994) observaram que a imersão das brotações em meio líquido causou maior efeito prejudicial ao enraizamento das brotações em genótipos de maior dificuldade de enraizamento, pois

Tabela 3. Altura e número de raízes primárias de plantas de dois porta-enxertos de macieira, após 49 dias de enraizamento in vitro, sob efeito de três substratos para desenvolvimento das raízes adventícias. Lavras, Ufla, 1999(1).

\begin{tabular}{lccccc}
\hline Substrato & \multicolumn{2}{c}{ Altura da planta $(\mathrm{cm})$} & & \multicolumn{2}{c}{ Raízes primárias $\left(\mathrm{n}^{\circ}\right)$} \\
\cline { 2 - 3 } \cline { 5 - 6 } & Marubakaido & M-26 & & Marubakaido & M-26 \\
\hline Ágar & $2,51 \mathrm{aA}$ & $2,01 \mathrm{aB}$ & & $9,91 \mathrm{aA}$ & $0,66 \mathrm{aB}$ \\
Vermiculita & $2,05 \mathrm{aA}$ & $1,09 \mathrm{bB}$ & & $0,20 \mathrm{cA}$ & $0,00 \mathrm{bA}$ \\
Plantmax & $1,77 \mathrm{bA}$ & $1,18 \mathrm{bB}$ & & $2,00 \mathrm{bB}$ & $4,02 \mathrm{aA}$ \\
\hline
\end{tabular}

${ }^{(1)}$ Médias seguidas de mesma letra, minúscula na coluna e maiúscula na linha, não diferem pelo teste de Tukey a $5 \%$ de probabilidade; os coeficientes de variação em relação à altura da planta e número de raízes primárias foram de $14,04 \%$ e $23,77 \%$, respectivamente. 
a deficiência de oxigênio nas camadas de células externas, adjacentes ao meio de cultura, inibiu o desenvolvimento das raízes. Além disso, como afirmam Pinker et al. (1995), em trabalho com Tilia cordata, a sobrevivência de brotações é maior quando o enraizamento ocorre in vitro e é acompanhado de um pré-condicionamento, com uso de substratos porosos e menor umidade, favorecendo a aclimatização.

Apesar disso, a vermiculita foi o substrato menos eficiente, provavelmente devido aos grandes espaços intercelulares existentes nesse material, o que dificulta a aderência do explante e causa a sua morte. Esta observação está de acordo com os resultados obtidos por Avanzato \& Cherubini (1993), que constataram uma relação inversa entre a capacidade de retenção de água do substrato e a sua capacidade em promover o desenvolvimento das raízes. Esses autores observaram melhor desenvolvimento de raízes adventícias de macieira 'MM 106' quando utilizado como substrato a perlita, cuja característica principal é a excelente aderência ao explante, mantendo as células túrgidas e com maior capacidade de multiplicação, o que está diretamente associado ao desenvolvimento das raízes. Entretanto, Nunes et al. (1999) atestaram ser a vermiculita o substrato mais eficiente para a aclimatização. Os resultados mais favoráveis obtidos por esses autores em relação ao presente trabalho podem ser atribuídos à graduação mais fina e ao uso de mudas já enraizadas.

Quando o desenvolvimento das raízes ocorreu em vermiculita e em Plantmax, formaram-se raízes mais curtas e com maior densidade de pêlos radiculares, devido à maior aeração nesses substratos, em relação ao meio solidificado com ágar. Especialmente em 'Marubakaido', a morte de brotações foi muito elevada, atingindo 14,29\%(Plantmax) e 62,86\% (vermicu- lita). Nesses substratos, ocorreu maior morte de brotações em 'Marubakaido'. Isto ocorreu provavelmente porque as brotações do 'M-26' possuem composição morfológica diferente das do 'Marubakaido', com brotações mais espessas e com maior teor relativo de água e reservas, o que, provavelmente, permitiu a sobrevivência da brotação mesmo sem o seu enraizamento. Portanto, as brotações de 'Marubakaido' enraízam com maior facilidade, porém as de 'M-26' resistem melhor ao dessecamento e à morte antes do enraizamento. McCown (1988) menciona que a qualidade da brotação é fundamental para o enraizamento e a aclimatização. Neste trabalho, a composição morfológica de 'M-26' favoreceu o enraizamento e a sobrevivência.

A presença de espaços porosos no substrato, embora favoreça a aeração, pode prejudicar o enraizamento in vitro, o que pode ser comprovado quando utilizado o ágar, condição em que nenhuma brotação morreu. Comparando-se esses resultados com os obtidos na primeira fase do experimento, no qual a vermiculita proporcionou porcentuais de enraizamento in vitro equivalentes aos do ágar, podese afirmar que a aeração parece ser mais importante na fase de indução do que propriamente durante 0 desenvolvimento das raízes adventícias, embora, como mencionado por Hutchinson (1984), utilizando-se a areia como meio de enraizamento in vitro, o aumento no número e comprimento de raízes pode ser devido à aeração do meio, pois há relação direta entre este fator e o enraizamento das brotações. Segundo George (1993), o enraizamento é um fenômeno que implica o uso de reservas da brotação ou estaca, para o qual é requerida uma intensa atividade respiratória e, para tanto, a aeração no substrato é importante. Caldas et al. (1998) mencionaram que, na

Tabela 4. Enraizamento e morte de brotações de dois porta-enxertos de macieira, após 49 dias de enraizamento in vitro, sob efeito de três substratos para desenvolvimento das raízes adventícias. Lavras, Ufla, 1999(1).

\begin{tabular}{lccccc}
\hline \multirow{2}{*}{ Substrato } & \multicolumn{2}{c}{ Enraizamento (\%) } & & \multicolumn{2}{c}{ Morte de brotações (\%) } \\
\cline { 2 - 3 } \cline { 5 - 6 } & Marubakaido & M-26 & & Marubakaido & M-26 \\
\hline Ágar & $85,71 \mathrm{aA}$ & $72,14 \mathrm{aA}$ & & $0,00 \mathrm{bA}$ & $00 \mathrm{aA}$ \\
Vermiculita & $5,71 \mathrm{bA}$ & $0,00 \mathrm{bA}$ & & $62,86 \mathrm{aA}$ & $2,86 \mathrm{aB}$ \\
Plantmax & $28,57 \mathrm{bB}$ & $71,43 \mathrm{aA}$ & & $14,29 \mathrm{bA}$ & $2,86 \mathrm{aB}$ \\
\hline
\end{tabular}

${ }^{(1)}$ Médias seguidas de mesma letra, minúscula na coluna e maiúscula na linha, não diferem pelo teste de Tukey a 5\% de probabilidade; os coeficientes de variação em relação enraizamento e a morte de brotações foram de $23,36 \%$ e $21,33 \%$, respectivamente 
fase de enraizamento in vitro, a vermiculita, umedecida com solução nutritiva, pode favorecer a formação de raízes, pelo maior grau de aeração que proporciona.

Ao final do período de aclimatização, a sobrevivência foi afetada somente pelo substrato, e somente houve diferença entre o ágar e a vermiculita (Tabela 5). É provável, entretanto, que o longo período destinado ao enraizamento (49 dias) tenha afetado negativamente a sobrevivência das plantas. A altura das plantas diferiu entre substratos apenas em 'Marubakaido', e o desenvolvimento das raízes em ágar ou Plantmax proporcionou os maiores valores (2,64 e 2,32 cm, respectivamente). Não houve diferença entre porta-enxertos para quaisquer substratos. O número de raízes primárias foi afetado pelos fatores estudados, obtendo-se os maiores valores em ágar e Plantmax, em ambos os porta-enxertos. Nesses dois substratos, o número de raízes primárias em 'M-26' foi significativamente maior do que em 'Marubakaido'. Constata-se, assim, que em ambos os porta-enxertos, os maiores valores para as variáveis analisadas após a aclimatização foram obtidos com ágar e Plantmax como substratos para o desenvolvimento in vitro das raízes. Os resultados obtidos neste experimento estão em acordo com os obtidos por Hutchinson (1984) que, trabalhando com macieira, nas fases de enraizamento e aclimatização, obtiveram bons resultados com areia, perlita e ágar, o que não ocorreu quando foram utilizadas a celulose e a vermiculita. Já Aldrufeu (1987) sugeriu, para o enraizamento in vitro de Pelargonium zonale, o uso da celulose, perlita e vermiculita. Embora Druart et al. (1997) tenham observado que o ágar foi dispensável quando utilizada a vermiculita umedecida com água no enraizamento de brotações de macieira e tenham mencionado que a falta de aeração no substrato inibiu o enraizamento in vitro, neste trabalho foi constatada a importância do ágar na rizogênese desses porta-enxertos.

A matéria seca, das raízes e da parte aérea, foi afetada pelos fatores estudados, e foi significativa a interação entre eles (Tabela 6). Para ambas as variáveis, em 'Marubakaido', o ágar proporcionou o melhor resultado, e em 'M-26' os maiores valores foram obtidos com ágar e com Plantmax. Houve diferença entre porta-enxertos quando utilizado o Plantmax (MS das raízes e MS da parte aérea), bem como com a vermiculita (MS da parte aérea).

Tabela 5. Sobrevivência, altura das plantas e número de raízes primárias de dois porta-enxertos de macieira após 49 dias de aclimatização sob efeito de três substratos para desenvolvimento das raízes adventícias. Lavras, Ufla, 1999(1).

\begin{tabular}{|c|c|c|c|c|c|c|}
\hline \multirow[t]{2}{*}{ Substrato } & \multicolumn{2}{|c|}{ Sobrevivência (\%) } & \multicolumn{2}{|c|}{ Altura da planta $(\mathrm{cm})$} & \multicolumn{2}{|c|}{ Raízes primárias $\left(\mathrm{n}^{\circ}\right)$} \\
\hline & Marubakaido & M-26 & Marubakaido & M-26 & Marubakaido & M-26 \\
\hline Ágar & $41,57 \mathrm{aA}$ & $44,64 \mathrm{aA}$ & $2,64 \mathrm{aA}$ & $2,27 \mathrm{aA}$ & $14,96 \mathrm{aB}$ & $25,20 \mathrm{aA}$ \\
\hline Vermiculita & $8,33 \mathrm{bA}$ & $14,29 \mathrm{bA}$ & $1,50 \mathrm{bA}$ & $1,72 \mathrm{aA}$ & $2,20 \mathrm{bA}$ & $8,80 \mathrm{bA}$ \\
\hline Plantmax & $32,14 \mathrm{abA}$ & $37,62 \mathrm{abA}$ & $2,32 \mathrm{aA}$ & $1,88 \mathrm{aA}$ & $11,32 \mathrm{aB}$ & $33,84 \mathrm{aA}$ \\
\hline
\end{tabular}

${ }^{(1)}$ Médias seguidas de mesma letra, minúscula na coluna e maiúscula na linha, não diferem pelo teste de Tukey a $5 \%$ de probabilidade; os coeficientes de variação em relação à sobrevivência, altura da planta e ao número de raízes primárias foram de $29,77 \%, 17,26 \%$ e $24,97 \%$, respectivamente.

Tabela 6. Matéria seca das raízes e da parte aérea de plantas de dois porta-enxertos de macieira, após 49 dias de aclimatização, sob efeito de três substratos para desenvolvimento das raízes adventícias. Lavras, Ufla, 1999(1).

\begin{tabular}{lccccc}
\hline Substrato & \multicolumn{2}{c}{ Matéria seca das raízes $(\mathrm{mg} /$ planta) } & & \multicolumn{2}{c}{ Matéria seca da parte aérea (mg/planta) } \\
\cline { 2 - 3 } \cline { 5 - 6 } & Marubakaido & M- 26 & & Marubakaido & M-26 \\
\hline Ágar & $64,20 \mathrm{aA}$ & $73,70 \mathrm{aA}$ & & $74,70 \mathrm{aA}$ & $77,80 \mathrm{aA}$ \\
Vermiculita & $4,00 \mathrm{bA}$ & $17,40 \mathrm{bA}$ & & $4,70 \mathrm{bB}$ & $26,50 \mathrm{bA}$ \\
Plantmax & $18,30 \mathrm{bB}$ & $71,80 \mathrm{aA}$ & & $27,3 \mathrm{bB}$ & $83,50 \mathrm{aA}$ \\
\hline
\end{tabular}

${ }^{(1)}$ Médias seguidas de mesma letra, minúscula na coluna e maiúscula na linha, não diferem entre si pelo teste de Tukey a $5 \%$ de probabilidade; os coeficientes de variação em relação à matéria seca das raízes e da parte aérea foram de $25,76 \%$ e $27,60 \%$, respectivamente 
Quando o substrato influenciou o enraizamento in vitro, observou-se que as características das raízes adventícias também tiveram efeito sobre o crescimento das plantas durante a aclimatização, o que demonstra a importância da condição da planta ao deixar o cultivo in vitro. O ágar provoca redução da disponibilidade de oxigênio (Moncousin, 1991). Embora essa redução não tenha prejudicado a rizogênese, sua substituição por outros materiais, como o Plantmax, mostrou-se promissora. Porém, alguns ajustes deste método deverão ser buscados, como forma de viabilizar o seu uso e obter maior enraizamento in vitro e melhor qualidade do sistema radicular, com influência sobre a aclimatização.

\section{Conclusões}

1. O substrato afeta o crescimento das plantas dos porta-enxertos de macieira 'Marubakaido' e 'M-26' nas fases de indução, e desenvolvimento, in vitro, das raízes adventícias.

2. A indução do enraizamento é mais eficiente em ágar, seguido da mistura vermiculita + ágar, nos dois porta-enxertos estudados.

3. O melhor desenvolvimento das raízes adventícias em brotações dos porta-enxertos 'Marubakaido' e 'M-26' é obtido com emprego do ágar, porém a maior sobrevivência é obtida com plantas enraizadas em meio geleificado com ágar e em Plantmax.

\section{Referências}

ALDRUFEU, A. Rooting and acclimatization of Pelargonium zonale plantlets. Acta Horticulturae, Leuven, v. 212, p. 361-366, 1987.

APTER, R. C.; McWILLIAMS, E. L.; DAVIES JUNIOR, F. T. In vitro and ex vitro adventitious root formation in Asian jasmine (Trachelospermum asiaticum): I. Comparative morphology. Journal of the American Society for Horticultural Science, Alexandria, v. 118, n. 6, p. 902905, Nov. 1993.

AVANZATO, D.; CHERUBINI, S. Influenza del substrato sulla radicazione diretta di microtalee ex vitro di melo MM106. Informatore Agrario, Roma, v. 49, n. 25, p. 7778, 1993

CALDAS, L. S.; HARIDASAN, P.; FERREIRA, M. E. Meios nutritivos. In: TORRES, A. C.; CALDAS, L. S.;
BUSO, J. A. (Ed.). Cultura de tecidos e transformação genética de plantas. Brasília: Embrapa-SPI/EmbrapaCNPH, 1998. p. 87-132.

COLLET, G. F.; NOWBUTH, L.; LE, C. L. Comparison of the easy-to-root Jork 9 and Cepiland and the difficultto-root EMLA 9 and Lancep Malus M9 rootstocks in vitro. Advances in Horticultural Science, Florence, v. 8, n. 1, p. $45-48,1994$

DRUART, P.; OPATRNY, Z.; DE KLERK, G. J. Optimization of culture media for in vitro rooting of Malus domestica Borkh. cv. Compact Spartan. Biologia Plantarum, Dordrecht, v. 39, n. 1, p. 67-77, 1997.

GEORGE, E. F. Plant propagation by tissue culture: the technology. 2. ed. Edington: Exegetics, 1993. Part 1

GRATTAPAGLIA, D.; MACHADO, M. A. Micropropagação. In: TORRES, A. C.; CALDAS, L. S.; BUSO, J. A. (Ed.). Cultura de tecidos e transformação genética de plantas. Brasília: Embrapa-SPI/Embrapa-CNPH, 1998. p. 183-260.

HAISSIG, B. E.; RIEMENSCHNEIDER, D. E. Genetic effects on adventitious rooting. In: DAVIS, T. D.; HAISSIG, B. E.; SANKHLA, N. (Ed.). Adventitious root formation in cuttings. Portland: Diocorides, 1988. p. 47-60.

HARTMANN, H. T.; KESTER, D. E.; DAVIES JUNIOR, F. T. Plant propagation: principles and practices. 5. ed. Englewood Cliffs: Prentice Hall, 1990. 647 p.

HUTCHINSON, J. F. Factors affecting shoot proliferation and root initiation in organ cultures of the apple 'Northern Spy'. Scientia Horticulturae, Amsterdam, v. 22 , n. 4, p. $347-358,1984$.

JONES, A. L.; ALDWINCKLE, H. S. Compendium of apple and pear diseases. St. Paul: APS, 1991. 100 p.

LE, C. L.; COLLET, G. F. Micropropagation de portegreffe de pommier: III. Acclimatation de Malus pumila Mill. (M.26, MAC.9) et de Malus domestica Borkh. cv. Golden Delicious. Revue Suisse de Viticulture, Arboriculture et Horticulture, Nyon, v. 23, n. 3, p. 201-204, 1991.

LEITE, G. B. Efeito de reguladores de crescimento, substratos, sacarose e intensidade luminosa na micropropagação de pereira (Pyrus communis $\mathbf{L}$.) cv. Bartlett e do clone OH x F97. Pelotas: UFPel, 1995. 50 p. Dissertação de Mestrado.

McCOWN, B. H. Adventitious rooting of tissue cultured plants. In: DAVIS, T. D.; HAISSIG, B. E.; SANKHLA, 
N. (Ed.). Adventitious root formation in cuttings Portland: Diocorides, 1988. p. 289-302.

MONCOUSIN, C. Rooting of in vitro cuttings. In: BAJAJ Y. P. S. (Ed.). Biotechnology in agriculture and forestry: high tech and micropropagation I. Berlin: Springer, 1991. p. 231-261

MURASHIGE, T.; SKOOG, F. A revised medium for rapid growth and bioassays with tobacco tissue cultures. Physiologia Plantarum, Copenhagen, v. 15, n. 3, p. 473 497, 1962

NAVATEL, J. C.; BOURRAIN, L. Influence of the physical structure of the medium on in vitro rooting Advances in Horticultural Science, Florence, v. 8, n. 1, p. 57-59, 1994.
NUNES, J. C. de O; BARPP, A.; SILVA, F. C.; PEDROTTI, E. L. Micropropagação do porta-enxerto 'Marubakaido'(Malus prunifolia) a partir da cultura de meristemas. Revista Brasileira de Fruticultura, Jaboticabal, v. 21, n. 2, p. 191-195, 1999.

PINKER, I.; JESCH, H. H.; KLAUSCH, A. Bewurzelung und Akklimatisation in vitro vermehrter Tilia cordata 'Wega'-Sprosse. Gartenbauwissenschaft, Stuttgart, v. 60, n. 6, p. 253-258, 1995.

SIMÕES, M. O. M. Ontogênese de gemas e raízes adventícias de Citrus sinensis (Linn.) Osbeck cv. Pêra cultivadas in vitro. Viçosa, MG: UFV, 1988. 56 p. Dissertação de Mestrado. 